\title{
Simple and rapid protocol for the isolation of PCR-amplifiable DNA from medicinal plants
}

\author{
A.A. Alatar ${ }^{1}$, M.A. Mahmoud ${ }^{1,3}$, S.A. Al-Sohaibani ${ }^{1}$ and \\ K.A. Abd-Elsalam ${ }^{1,2,3}$ \\ ${ }^{1}$ Botany and Microbiology Department, College of Science, \\ King Saud University, Riyadh, Saudi Arabia \\ ${ }^{2}$ Center of Excellence in Biotechnology Research, \\ King Saud University, Riyadh, Saudi Arabia \\ ${ }^{3}$ Plant Pathology Research Institute, Agricultural Research Center, Giza, Egypt \\ Corresponding author: K.A. Abd-Elsalam \\ E-mail: abd-elsalam.k.a@post.com
}

Genet. Mol. Res. 11 (1): 348-354 (2012)

Received February 22, 2011

Accepted October 7, 2011

Published February 13, 2012

DOI http://dx.doi.org/10.4238/2012.February.13.1

\begin{abstract}
Medicinal plant species has a valuable economic importance because of its usage as pharmaceuticals, nutritional, as well as its use in popular medication. For DNA-based techniques, nanogram quantities of the purified DNA are requisite to amplify and yield sufficient amounts of PCR products. SDS-based DNA isolation method was used to extract DNA from 11 species of different aromatic and medicinal plants collected from Saudi Arabia. Three hundred milligrams of fresh shredded plant material was necessary. The DNA purity was further confirmed by agarose gel, restriction endonuclease digestion and microsatellite primedpolymerase chain reaction (MP-PCR). DNA yields ranged from 10$20 \mu \mathrm{g}$ (in $100-\mu \mathrm{L}$ elution volumes) from all plant material evaluated. The DNA obtained was free of any contaminating proteins, polysaccharides and colored pigments. The extracted genomic DNA was found suitable for restriction digestion and PCR amplification. Our experimental procedure provides an easy, suitable, non-toxic,
\end{abstract}


cheap, and quick process for the amplification of DNA from medical plant tissue.

Key words: Restriction endonuclease digestion; DNA isolation; Artemisia monosperma; Citrullus colocynthis

\section{INTRODUCTION}

Medicinal plants have played a key role in world health. Plants contain hundreds of constituents and a variety of them are very toxic, such as the most cytotoxic anti-cancer plant-derived drugs, digitalis, pyrrolizidine alkaloids, etc. However, the adverse effects of phytotherapeutic agents are less frequent compared to synthetic drugs (Calixto, 2000). The plant flora of Saudi Arabia is one of the richest biodiversity areas in the Arabian Peninsula and comprises very important genetic resources of crop and medicinal plants (Mossa et al., 1987). Medicinal plants of Saudi Arabia include 300 species from the flora, representing $12 \%$ of the total species of the flora (Rahman et al., 2004). Numerous methods described for plant DNA isolation fail to generate high-quality DNA from medicinal herbs and aromatic plants. Medicinal plants contain high levels of polysaccharides, polyphenols, several pigments, and other secondary metabolites, which makes DNA unusable for downstream work in molecular biology research (Wen and Deng, 2002). Polyphenols as powerful oxidizing agents can decrease the yield and purity of extracted DNA. Polysaccharides make DNA viscous, glue-like and non-amplifiable in PCR by inhibiting Taq polymerase enzyme activity and also interfere with accurate DNA digestion (Porebski et al., 1997).

A good isolation protocol should be simple, rapid and efficient, yielding appreciable amounts of high-quality DNA suitable for molecular analysis (Križman et al., 2006). Different methods for DNA extraction have effectively been applied for many plant species. DNA has been treated with DNase-free ribonuclease A, since large amounts of RNA in the sample can chelate $\mathrm{Mg}^{2+}$ and reduce yield in PCR. It also involves successive long-term RNAse treatment with all steps carried out at room temperature. RNase treatment degrades RNA into small ribonucleosides that do not contaminate the DNA preparation and yields RNA-free pure DNA (Jena et al., 2010). RNA contamination was removed by dissolving nucleic acids in the presence of RNase (Matasyoh et al., 2008; Muge et al., 2009).

At present, there are several DNA isolation kits, but the main problem with these commercially available kits is their high cost per sample (Ahmed et al., 2009). Because most of the available procedures are based on the use of commercial kits, routine DNA extraction is economically difficult for large scale genomic applications. Therefore, the purpose of this study was to optimize an efficient but low-cost method to isolate high-quality DNA from medicinal plants in Saudi Arabia.

\section{MATERIAL AND METHODS}

\section{Plant material}

To facilitate better homogenization, leaf tissue was used for the experimental study. Keeping in mind criteria for the collection, fresh leaves were collected from similar environmental 
conditions for DNA isolation studies. In the current research, young and old leaves were collected from 11 different plant species. The medicinal plant species used in this study are listed in Table 1.

\begin{tabular}{|c|c|c|c|}
\hline$\underline{\text { Sample number }}$ & Scientific name & English name & Plant family \\
\hline 1 & Artemisia monosperma & Tarragon & Asteraceae \\
\hline 2 & Haloxylon salicornicum & Lana & Chenopodiaceae \\
\hline 3 & Citrullus colocynthis & Colocynth & Cucurbitaceae \\
\hline 4 & Haloxylon salicornicum & Lana & Chenopodiaceae \\
\hline 5 & Pulicaria undulata & Wild tea & Asteraceae \\
\hline 6 & Artemisia seiberi & Tarragon & Asteraceae \\
\hline 7 & Artemisia seiberi & Tarragon & Asteraceae \\
\hline 8 & Achillea fragrantissima & Lavender cotton & Asteraceae \\
\hline 9 & Senna italica & Senna & Caesalpiniaceae \\
\hline 10 & Trichodesma africanum & Blue-bells & Boraginaceae \\
\hline 11 & Callingonum comosim & Abal & Polygonaceae \\
\hline 12 & Ocimum basilicum & Sweet basil & Lamiaceae \\
\hline 13 & Teucrium polium & Felty germander & Lamiaceae \\
\hline
\end{tabular}

\section{DNA extraction method}

Optimization of the conventional sodium dodecyl sulfate (SDS) extraction method was according to the procedure of Moslem et al. (2010). A freshly harvested leaf sample (300 mg) was ground in liquid nitrogen using a mortar and pestle, and leaves were rapidly transferred to $600 \mu \mathrm{L}$ freshly prepared preheated $\left(65^{\circ} \mathrm{C}\right)$ extraction buffer. Ten microliters of RNaseA (10 $\mu \mathrm{g} / \mathrm{mL}$ ) was added and microtubes were incubated at $65^{\circ} \mathrm{C}$ in a hot water bath for 15 min with occasional shaking and swirling for every 5 min. Protein was precipitated by the addition of $150 \mu \mathrm{L} 3 \mathrm{M}$ sodium acetate, $\mathrm{pH} 5.3$, with thorough mixing by inverting the tube. The mixture was centrifuged at $10,000 \mathrm{rpm}$ for $10 \mathrm{~min}$ at room temperature. The supernatant was carefully decanted and transferred to a fresh tube and an equal volume of cold 2-propanol was added; fibrous DNA was precipitated with gentle stirring and was incubated at room temperature for $10 \mathrm{~min}$. Genomic DNA was collected by centrifuging at 10,000 rpm for $10 \mathrm{~min}$. The resulting pellet was washed twice with $80 \%$ ethanol and then centrifuged at $9000 \mathrm{rpm}$ for $2 \mathrm{~min}$. The pellet obtained was dried under vacuum using Vacufuge Concentrators 5301 (Eppendorf) at $37^{\circ} \mathrm{C}$ for $5 \mathrm{~min}$. About $2 \mu \mathrm{g}$ DNA was used for restriction digestion and $25 \mathrm{ng}$ for PCR amplification.

\section{Evaluation of quantity and quality of DNA}

DNA purity was checked by electrophoresis of the extracted genomic DNA on $1.5 \%$ agarose gel at $100 \mathrm{~V}$ for $120 \mathrm{~min}$ in $1 \mathrm{X}$ TAE (Tris-base, glacial acetic acid, 0.5 M EDTA) gel buffer on a submerged agarose gel electrophoresis. The gel was stained with $0.25 \mu \mathrm{g} / \mathrm{mL}$ ethidium bromide for the visualization of gDNA. UVIsoft analysis (Gel Documentation and Analysis Systems, Uvitec, Cambridge, UK) was used to capture the images and to calculate molecular size.

\section{DNA digestions}

To determine the suitability of DNA for restriction digestion, $2 \mu \mathrm{g}$ DNA was subjected to digestion with the $C f o$ I enzyme (Roche, Germany). DNA was incubated for $3 \mathrm{~h}$ at $37^{\circ} \mathrm{C}$ with 
$1 \mathrm{U}$ enzyme, $2 \mu \mathrm{L}$ digestion buffer and $1 \mu \mathrm{L}$ sterilized water. The digested DNA was confirmed on a $1.5 \%$ agarose gel.

\section{Microsatellite-primed PCR (MP-PCR) amplification}

MP-PCR patterns were produced following the protocol of Abd-Elsalam et al. (2011). PCR products were obtained in a total volume of $25 \mathrm{~mL}$ with $20 \mathrm{ng}$ template DNA, 10 pmol of the primer T3B (5'-AGGTCGCGGGTTCGAATCC-3') and M13 (5'-GAGGGTGGCGGTTCT-3') (MWG, Germany), $200 \mathrm{mM}$ of each dNTP, $1 \mathrm{U}$ Taq polymerase (JenaBioscience, Germany) and $1 \mathrm{X}$ polymerase reaction buffer. DNA and PCR mixture were amplified in Techne TC-312 (Techne, Stone, UK). The PCR parameters consisted of 1 cycle of 2 min at $94^{\circ} \mathrm{C}$ followed by 40 cycles of denaturation at $94^{\circ} \mathrm{C}$ for $1 \mathrm{~min}$, annealing at $52^{\circ} \mathrm{C}$ for $90 \mathrm{~s}$ and extension at $72^{\circ} \mathrm{C}$ for $2 \mathrm{~min}$. The thermal profile ended with a final extension at $72^{\circ} \mathrm{C}$ for $6 \mathrm{~min}$. The amplified products were loaded on a $1.5 \%$ agarose gel containing $5 \mathrm{~mL}$ ethidium bromide and subjected to electrophoresis at $100 \mathrm{~V}$. DNA was visualized by UV fluorescence after staining with ethidium bromide.

\section{RESULTS}

\section{DNA yield and purity}

Cell wall disruption methods basically depended on liquid nitrogen freezing and grinding with a mortar and pestle. DNA quality was assayed by direct electrophoresis, showing the absence of polyphenols and no signs of degradation (Figure 1).

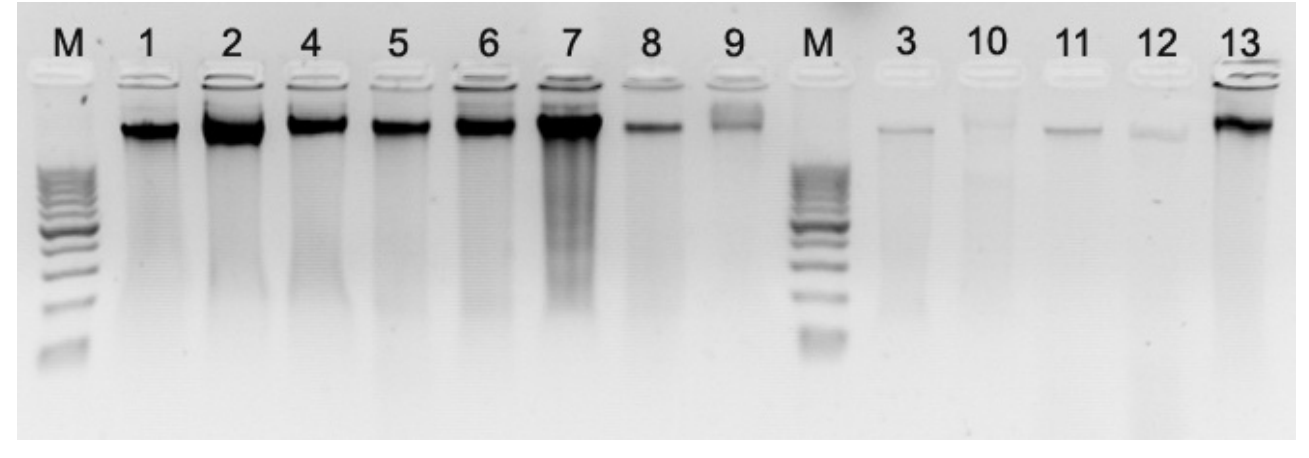

Figure 1. DNA extracted from fresh leaf tissue on 1.5\% (w/v) agarose gel. Lane $1=$ Artemisia monosperma; lane $2=$ Haloxylon salicornicum; lane $3=$ Citrullus colocynthis; lane $4=H$. salicornicum; lane $5=$ Pulicaria undulata; lane $6=$ Artemisia seiberi; lane $7=$ A. seiberi; lane $8=$ Achillea fragrantissima; lane $9=$ Senna italica; lane 10 = Trichodesma africanum; lane $11=$ Callingonum comosim; lane $12=$ Ocimum basilicum; lane $13=$ Teucrium polium; lane $M=100$-bp DNA ladder size marker (JenaBioscience).

The extracted DNA from plants is totally digestible with $1 \mathrm{U} C f o \mathrm{I}$ per $\mu \mathrm{g}$ DNA and shows no detectable RNA contamination as determined by agarose gel electrophoresis (Figure 2). No smearing DNA appeared on the gel, although the marker fragment of $100 \mathrm{bp}$ was clearly visible. Using our procedure, 10-20 $\mu \mathrm{g}$ DNA per tube are typically obtained, enough 


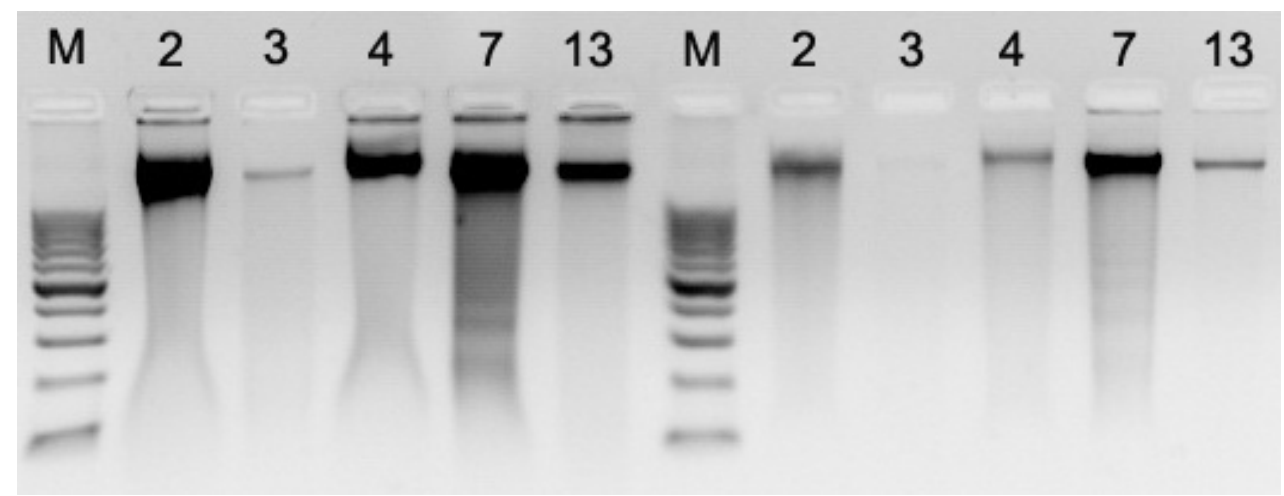

Figure 2. Endonuclease restriction digest of genomic DNA from plant species. Lane $1=$ Haloxylon salicornicum; lane 2 =Citrullus colocynthis; lane $3=H$. salicornicum; lane $4=$ Artemisia seiberi; lane $5=$ Teucrium polium; lane $M=100-b p$ DNA ladder size marker (JenaBioscience).

for several runs of PCR-based assays. However, the quantity as well as the quality of the extracted genomic DNA were high enough to perform hundreds of PCR-based reactions. Figure 3 shows an electrophoretic agarose gel with the MP-PCR fingerprinting obtained using the primer T3B on the DNA of 13 different plant species. Electrophoretic analysis shows that the DNA was, in most of the samples, in the 2000-10,000-bp size range. These results proved that the isolated DNA is useful for plant species fragment amplification and microsatellite analysis.

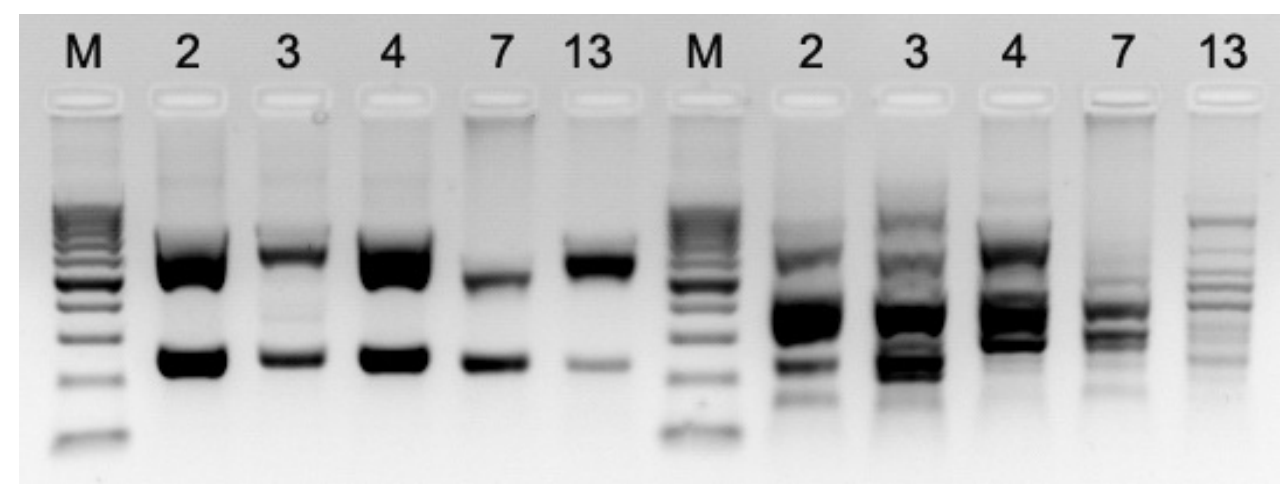

Figure 3. T3B and M13 microsatellite-primed PCR (MP-PCR) amplification for various plant species using DNA extracted following the present method. Lane $1=$ Haloxylon salicornicum; lane 2 =Citrullus colocynthis; lane $3=$ H. salicornicum; lane $4=$ Artemisia seiberi; lane $5=$ Teucrium polium; lane $M=100$-bp DNA ladder size marker (JenaBioscience).

\section{DISCUSSION}

Saudi Arabia can be considered as a store house of high importance medicinal and aromatic plant diversity in Arabian Peninsula. The isolation of genomic DNA from plant species is faced with problems that include: 1) degradation of DNA due to endonucleases, 2) co-isolation of highly viscous polysaccharides, and 3) co-isolation of inhibitory compounds 
such as polyphenols and other secondary metabolites, which directly or indirectly interfere with enzymatic reactions (Mishra et al., 2008; Niu et al., 2008; Amani et al., 2011). We report an improved technique of DNA extraction from plants with high levels of polyphenols and polysaccharides. The DNA resulting from the optimized protocol was observed to be largely free from polyphenolics and secondary metabolites, as determined by successful digestion with restriction endonucleases and PCR amplification. All methods have in common the use of detergents such as SDS for cell wall lysis, and this often inhibits further purification manipulations (Melo et al., 2006). Rapid and direct transfer of homogenized plant material to an extraction buffer heated at $65^{\circ} \mathrm{C}$ minimized the chance of activation of all types of endogenous nucleases. However, RNA-free DNA can be obtained by treating the extracts with RNAse A. The presence of RNA in DNA extracts is not a major problem as this usually does not interfere with PCR or restriction digestion. The addition of $3 \mathrm{M}$ sodium acetate and ethanol increases the solubility of polysaccharides, thereby effectively decreasing co-precipitation of the polysaccharides and DNA. Polysaccharides are known to precipitate in 2-propanol and ethanol (Manna et al., 1996). The quantity of the DNA isolated is 10-20 $\mu \mathrm{g}$ from plant material. The DNA yield and quality are sufficient for approximately hundreds of PCR reactions. We obtained DNA yield and quality similar to that reported with other methods (Chandra and Tewari, 2007). The DNA obtained using this method was consistently amplifiable, using MP-PCR, making it very useful in genetic diversity analysis of plant species. Microsatellite DNA markers are now among the most preferred markers. They are preferred because they have a high degree of polymorphism between and within plant species; they are also easy to detect and are publicly available for some plant species (McCouch et al., 2002). The method offered in this paper eliminates much of the laborious and time-consuming steps of most other protocols (Płaza et al., 2004). In conclusion, the isolated DNA yielded high quantities from small amounts of plant tissue, and had good spectral qualities amenable to restriction endonuclease digestion and PCR amplification. The working protocol presented proved to be valid and suitable for a wider range of medicinal plant research and should also be applicable in high throughput for routine DNA studies in minimally equipped laboratories.

\section{ACKNOWLEDGMENTS}

Research supported by grants from the National Plan of Science and Technology, King Abdulaziz City of Science and Technology, Riyadh, Saudi Arabia (\#10-Env1276-97102), and also by the Center of Excellence in Biodiversity, King Saud University.

\section{REFERENCES}

Abd-Elsalam K, Bahkali AH, Moslem M, De Wit PJ, et al. (2011). Detection of Mycosphaerella graminicola in wheat leaves by a microsatellite dinucleotide specific-primer. Int. J. Mol. Sci. 12: 682-693.

Ahmed I, Islam M, Arshad W, Mannan A, et al. (2009). High-quality plant DNA extraction for PCR: an easy approach. J. Appl. Genet. 50: 105-107.

Amani J, Kazemi R, Abbasi AR and Salmanian AH (2011). A simple and rapid leaf genomic DNA extraction method for polymerase chain reaction analysis. Iran. J. Biotechnol. 9: 69-71.

Calixto JB (2000). Efficacy, safety, quality control, marketing and regulatory guidelines for herbal medicines (phytotherapeutic agents). Braz. J. Med. Biol. Res. 33: 179-189.

Chandra A and Tewari S (2007). Isolation of genomic DNA from Stylo species without liquid nitrogen suitable for RAPD and STS analyses. Cytologia 72: 287-293. 
Jena RC, Samal KC and Das BK (2010). Optimization of DNA isolation and PCR protocol for RAPD analysis of Mangifera indica L. J. Agric. Technol. 6: 559-571.

Križman M, Jakše J, Baričevič D, Javornik B, et al. (2006). Robust CTAB-activated charcoal protocol for plant DNA extraction. Acta Agric. Slov. 87: 427-433.

Manna B, Gambhir A and Ghosh P (1996). Production and rheological characteristics of the microbial polysaccharide gellan. Lett. Appl. Microbiol. 23: 141-145.

Matasyoh LG, Wachira FN, Kinyua MG, Muigai AWT, et al. (2008). Leaf storage conditions and genomic DNA isolation efficiency in Ocimum gratissimum L. from Kenya. Afr. J. Biotechnol. 7: 557-564.

McCouch SR, Teytelman L, Xu Y, Lobos KB, et al. (2002). Development and mapping of 2240 new SSR markers for rice (Oryza sativa L.). DNA Res. 9: 199-207.

Melo SC, Pungartnik C, Cascardo JC and Brendel M (2006). Rapid and efficient protocol for DNA extraction and molecular identification of the basidiomycete Crinipellis perniciosa. Genet. Mol. Res. 5: 851-855.

Mishra MK, Rani NS, Ram AS, Sreenath HL, et al. (2008). A simple method of DNA extraction from coffee seeds suitable for PCR analysis. Afr. J. Biotechnol. 7: 409-413.

Moslem MA, Bahkali AH, Abd-Elsalam KA and Wit PJ (2010). An efficient method for DNA extraction from Cladosporioid fungi. Genet. Mol. Res. 9: 2283-2291.

Mossa JS, Al-Yahya MA and Al-Meshal IA (1987). Medicinal Plants of Saudi Arabia. King Saud University Press, Riyadh.

Muge E, Burg K, Kadu C, Muchugi A, et al. (2009). Isolation of high quality DNA and RNA from cambium of the East African Greenheart (Warburgia ugandensis). Afr. J. Biotechnol. 8: 3036-3040.

Niu C, Kebede H, Auld DL, Woodward JE, et al. (2008). A safe inexpensive method to isolate high quality plant and fungal DNA in an open laboratory environment. Afr. J. Biotechnol. 7: 2818-2822.

Płaza GA, Upchurch R, Brigmon RL, Whitman WB, et al. (2004). Rapid DNA extraction for screening soil filamentous fungi using PCR amplification. Pol. J. Environ. Stud. 13: 315-318.

Porebski S, Bailey LG and Baum BR (1997). Modification of a CTAB DNA extraction protocol for plants containing high polysaccharide and polyphenol components. Plant Mol. Biol. Rep. 15: 8-15.

Rahman MA, Mossa JS, Al-Said MS and Al-Yahya MA (2004). Medicinal plant diversity in the flora of Saudi Arabia 1: a report on seven plant families. Fitoterapia $75:$ 149-161.

Wen XP and Deng XX (2002). The extraction of genomic DNA from five species of Rosa. Seed 126: 18-21. 